\title{
Tissue Procurement
}

National Cancer Institute

\section{Source}

National Cancer Institute. Tissue Procurement. NCI Thesaurus. Code C150718.

The removal of tissues from a donor for the purpose of transplantation. 